\title{
PROSPECTS OF CYPRUS SETTLEMENT AFTER THE HELSINKI SUMMIT
}

Ishtiaq Ahmad*

\section{Abstract}

The very factor that was being perceived by Turkish Cypriots prior to the December 1999 Helsinki European Council summit to pose the gravest danger to Cyprus settlement-namely, the European Union (EU) membership of Cyprus-may prove to be vital in settling the issue in the post-Helsinki period, provided the EU and the rest of the world community recognize the existence of two separate nations and two separate states on the island. In the light of historical realities and continued intransigence by Greek Cypriots, the establishment of federation or confederation in Cyprus is neither possible nor feasible. What is achievable is the division of the island into two states, which has already had a de facto existence since 1974 and, for which, the partition of British India into India and Pakistan over half century ago provides the most pertinent analogy. By resorting to this extreme option-that is, by giving de jure status to the existing partition in Cyprus - the international community, particularly the EU, may in fact start a reverse process, leading to the establishment of a two-states confederation in the initial phase and eventually a bi-zonal and bi-communal federation. As far as the question of the island's membership in EU is concerned, Brussels should consider the option of admitting the two states of Cyprus, one Greek Cypriot and another Turkish Cypriot, separately for EU membership. In this context, some valid precedents are available.

\section{Introduction}

The prospects of peace settlement in Cyprus are brighter than ever after the December 1999 Helsinki European Council summit. By deciding to start accession talks with South Cyprus, the December 1997 Luxembourg European Council summit had added a negative dimension to the Cyprus issue, forcing the Turkish Cypriot side to walk out of the UN-supervised face-to-face talks between leaders of the two Cypriot nations. On the contrary, even though the Helsinki summit also decided to continue the accession process with South

*Assistant Professor of International Relations at the Eastern Mediterranean University, Turkish Republic of Northern Cyprus. 
Cyprus, it has added a positive dimension to the issue by including Turkey as a candidate for EU membership. Perhaps the most important element in this new dimension is that the Turkish Cypriot leadership is no more considering the EU as a stumbling block to Cyprus settlement, as it did several years before and two years after the Luxembourg summit. Only one week after the Helsinki summit, Turkish Cypriot President Rauf Denktas proposed a settlement "within the EU" provided the EU recognized the Turkish Republic of Northern Cyprus (TRNC) as a separate entity on the island. ${ }^{1}$ The UN proximity talks on Cyprus, which had resumed in New York a week before the Helsinki summit, got an impetus from the summit conclusions. Consequently, both sides are now willing to negotiate within the UN framework, even though the Greek Cypriot leadership continues to show its traditional intransigent outlook.

The Helsinki summit conclusions (paragraph 9-a) welcomed "the launch of the talks aimed at a comprehensive settlement of the Cyprus problem on December 3 in New York" and expressed "strong support for the UN SecretaryGeneral's efforts to bring the process to a successful conclusion. Paragraph 9b of the conclusions, however, stated: "The European Council underlines that a political settlement will facilitate the accession of Cyprus to the European Union. If no settlement has been reached by the completion of accession negotiations, the Council's decision on accession will be made without the above being a precondition. In this the Council will take account of all relevant factors." 2 The very reason why the summit conclusions mentioned to "consider all relevant factors" explains that some EU powers still maintain reservations on the feasibility of bringing a divided island with an unsettled political affair into the European fold. On various occasions in the recent past, France, Germany, Italy, Netherlands and Britain have raised their eyebrows over the question of Cyprus accession prior to the island's political settlement for similar reasons. ${ }^{3}$

As for Turkey's EU candidacy, in paragraph 12, the Helsinki summit conclusions stated: "Turkey is a candidate State destined to join the Union on the basis of the same criteria as applied to other candidate States. Building on the existing European strategy, Turkey, like all other candidate States, will benefit from a pre-accession strategy to stimulate and support its reforms. This will include enhanced political dialogue, with emphasis on progressing towards fulfilling the political criteria for accession with particular reference to the issue of human rights, as well as on the issues related to in paragraphs 4 and 9 (a)." Thus, even though the European Union did not try to establish a direct linkage between Turkey's EU candidacy and its stance towards Cyprus's EU accession process, it might expect Turkey to show some flexibility on the Cyprus issue, or, to be more pertinent, make some concessions on Cyprus prior to the island's accession with the EU so that political settlement of the issue could be reached before Cyprus is ready for accession? ${ }^{4}$ 
President Denktas's initial reaction to the Helsinki summit decision on the question of Cyprus accession was no doubt tough. The decision came as he and Greek Cypriot President Glafcos Clerides were participating in the first round of UN proximity talks that had resumed in New York on December 3, 1999. President Denktas accused the EU of bowing before Greek blackmailing tactics, adding that the Helsinki decision would make the division of Cyprus permanent. However, as soon as the Turkish Cypriot leader returned after attending these talks to Ankara, there was clear-cut shift in his stance on the matter. He said he did not expect the Greek Cypriots securing the island's EU membership before its political resolution. He also said that Turkey's EU candidacy might in fact help resolve the Cyprus issue, as in future Ankara would have greater role in European affairs. He argued that if the EU recognized the TRNC as a separate entity, then the Turkish Cypriot state might also apply for EU membership. According to him, if both the Greek Cypriot-administered southern Cyprus and the TRNC became EU members, there would be a Cyprus settlement. ${ }^{5}$

The European Union decision to grant candidacy status to Turkey is significant for Cyprus - as a similar future EU course for Turkish Cypriots, obviously preceded by Brussel's recognition of the TRNC, can settle the Cyprus issue. Obviously, for the purpose, an open-ended consent of the Greek Cypriot leadership remains a pre-requisite. Unfortunately, instead of capitalizing on the historic shift in Turkish Cypriot stance towards the EU, the Greek Cypriot leaders have chosen to be obstructionist once again. Such a reactionary attitude will only contribute to further widening of the prevailing civilizational divide in Cyprus-whose causes are essentially rooted in history. Centuries on, the Greek and Turkish people of the island have lived separately. They lived mostly in separate villages and townships. They went to separate schools. Interestingly, in all of these centuries, only a handful cases of inter-marriages were officially registered. This sufficiently proves the absence of cultural affinity exists between the two people. No proposal for peace in Cyprus should ignore this historical reality in Cyprus.

As there is no common Cypriot culture, there is no single Cyprus nation. But Greek Cypriot leaders always try to highlight 'Cypriotness' of the islanders, in order to dupe the outside world. As regards Cyprus today, the cultural divisions existing between the Greek and Turkish nations have sharpened due to decades of physical separation. Every passing day adds to this cultural and geographical divide. The Partnership Republic of 1960 was an utterly failed attempt on the part of the withdrawing colonial British to bring the two nations together. It did not work, primarily because Greek Cypriot leaders, thinking wrongly that their community was in majority on the island, were not prepared to recognize political equality of their Turkish Cypriot partners. ${ }^{6}$ The Republic 
could not survive, because of the fundamental fact that despite the creation of one Republic, the island still had within its boundaries two entirely different nations, with separate cultures, languages, and religions. These two nations have mistrusted each other for a long time. The nation of Greek Cypriots existed before 1571. But before the capture of Cyprus by the Ottomans in that year, the Greeks were not the rulers of the island. They were the subjects of the ruling Venetians. The Venetians, for being Catholic Christians, persecuted Orthodox Christian Greeks. The latter should at least be grateful to Turkish Cypriots today. For it were the forefathers of Turkish Cypriots, the Ottomans, who liberated Greek Cypriots, especially their holy priests, from Venetian reign of terror on the island.

Since 1963, the new generations of the two nations of Cyprus have lived in a climate full of bitterness and suspicion. Therefore, any international bid to bring them together again, or any UN effort to revive the 1960 experience, will only be counter-productive. Since 1974, there has been peace in Cyprus and the only way to let this peaceful situation continue well into the TwentyFirst Century is to divide the island. In this context, the Two-Nation-Theory, on the basis of which the Indian subcontinent was partitioned into Muslim majority Pakistan and Hindu majority India, can serve as an excellent precedent for the international community. In British India's case, it was the fear of Hindu domination which forced the Muslims to demand Pakistan; in the case of Cyprus, given the growing chauvinism of Orthodox Christian leadership of Greek Cyprus, the Turkish side-even though Islam fares nowhere in its political perception on the issue - is justified in demanding a separate state. Interestingly, despite the fact that Turkish Cypriots were ethnically-cleansed during 196374 , and despite the fact that Greek Cypriots continue to maintain a highly arrogant and distrustful attitude towards them, the Turkish Cypriot leadership has been flexible and friendly enough to make every possible bilateral and multilateral efforts over the years to reach a peaceful settlement.

The creation of Pakistan in 1947 was also necessitated by a similar chauvinistic attitude on the part of the Hindu leadership of British India. For its part, the Indian Muslim League led by Quaid-i-Azam Muhammad Ali Jinnah had even accepted the Cabinet Mission Plan of 1942, which proposed to create an Indian confederation, consisting of Muslim majority areas as one political entity and Hindu-majority areas as another-with the two states sharing foreign affairs, defense, and communications at the Centre. The Indian National Congress, led by Jawaharlal Nehru, rejected the Plan, which was the last British attempt to keep India united after their departure from the subcontinent. In a sense, the Cabinet Mission Plan's Confederation proposal can be equated with President Denktas's August 1998 Confederation proposal, which has been rejected by the Greek Cypriot leadership. The movement for creating Pakistan had picked 
up only after 1942, following the rejection of the Cabinet Mission Plan by Mr Nehru. The reason being that Jinnah and other Muslim League leaders had by then concluded that it was useless to be flexible with a leadership whose sole aim was to dominate and subjugate the Muslim minority population in a united India. Thus, until the time Pakistan was created-14 August 1947 - the Indian Muslim leaders struggled for one thing only: the creation of a separate Muslim state, where the people could live freely and happily. In an article published in the January-February 1997 issue of the Foreign Affairs, Radha Kumar has tried to create an extremely bleak image of Partition as a means of resolving intercommunal disputes. ${ }^{7}$ If she is to be believed, then all the ongoing movements of self-determination across the world should be counter-productive, and must be stopped by state authorities no matter how atrocious they are, and crushed by international organizations no matter how unjust their perceptions and policies are. Although she admits that "in many ways, despite the violence and displacements it produced, India's partition was the most successful ethnic partition, both because it allowed the British to quit and because the conflicts that ensued were by and large contained. But this had less to do with the wisdom of ethnic separation than with other factors, among them the subcontinent's distance from Europe." Does this mean the British should not have opted for the subcontinent's division into two states, were the region located closer to Europe?

As for Cyprus, Radha argues that the island's "partition can only be described as a partition by default that the UN presence inadvertently aided... While casualties have been restricted since (the Turkish intervention of 1974), the division of Cyprus is little more than a long standoff that remains volatile and continues to require the presence of UN troops. Nor can the conflict be confined to Cyprus. Over the 20 years since partition, its short fuse is evident. A violent demonstration of (Greek) Cypriots in August 1996 resulted in Greece and Turkey threatening war. The cost of containment, therefore, includes permanent vigilance on the part of NATO and the Atlantic allies."

In Cyprus's case, Radha's argument is beyond doubt based on sheer ignorance of a crucial ground reality: that since the 1974 Turkish intervention, the island has seen a greater level of peace than is visible in relations between many hostile neighbouring countries of the world. Take, for instance, the case of Kashmir, where across the Line of Control, the troops of nuclear India and Pakistan exchange artillery shells and mortar fire almost on a daily basis, causing several military and civilian casualties on the two sides. Thus, it is interesting to observe that while Radha Kumar has defended subcontinent's case for partition, despite the existence of a war-like situation between India and Pakistan over Kashmir, she refuses to accept the partition of Cyprus, on the basis of just one violent incident that occurred along the Green Line as far back as August 1996. 
The granting of the right of self-determination to the Turkish Cypriots would neither hamper the territorial integrity of South Cyprus, nor would it in any way negatively impact regional peace and stability. Rather, the exercise of this option would settle once and for all the Cyprus issue, by establishing two independent states on the island which would cooperate with each other the way all other members of the comity of nations are supposed to. The creation of two ethnically homogenous states in Cyprus will "eliminate the unacceptable strategic burden of UN peace-keeping expenses; enhance NATO's efficiency by reducing Greek-Turkish tensions; and reduce the diplomatic, financial and military costs of diverting resources to conflict containment in the Eastern Mediterranean." 8

The gory events occurring between December 1963 and July 1974 prove that the two nations of Cyprus cannot co-exist with each other peacefully. ${ }^{9}$ The mutual animosity and bickering between them-rooted in the 1960-63 Republic experience and in the 1963-74 ethnic-cleansing of Turkish Cypriots-have been crystallized in the minds of the two sides' ruling elite, if not the entire populations. The two nations could have co-existed peacefully in the 1960 Cyprus Republic. That they could not, was because of the domineering tendencies on the part of the Greek leadership who exhibited an insatiable lust for majority rule in Cyprus. Here, again, one would like to take an analogy from the Muslim experience in the British India. The call for Pakistan was for the first time made in the Lahore Resolution of March 23, 1940. What forced the Muslims of India to call for the partitioning of subcontinent and demand Pakistan? The immediate reason was the experience they had in Hindu majority states of British India after the provincial elections of 1937, which were held after the promulgation of the Government of India Act of $1935 .^{10}$

As a result of these elections, the Indian National Congress, an essentially Hindu political party, formed the governments in eight out of eleven provinces of British India, including the Hindu majority provinces. For the next twenty-eight months (1937-1939), the kind of persecution which the Muslims experienced at the hands of Hindu leaders of Congress convinced them that a United India with a Hindu-dominated Central government could seize their political fate once and for all. Thus, the Indian Muslim leadership thought it was better to demand an independent state before the British withdrawal - a demand that was made in the 1940 Lahore Resolution. As stated before, the Indian Muslim League led by Jinnah was flexible enough to accept the Confederation solution offered by the British in their Cabinet Mission Plan. However, after the rejection of the Plan by the Hindu leadership, the movement for Pakistan became so strong that the British were left with no option but to divide the subcontinent into two states on the basis of religion. 
If in the case of the subcontinent, the 'divide-and-quit' option determined. the end of British colonialism; in the case of Cyprus, the British opted for a federal solution. That they did this, was because unlike Indian Muslims, Turkish Cypriots did not demand the creation of a separate homeland. What their leadership demanded from the withdrawing colonial empire was political sovereignty and security guarantee. However, before the British withdrawal from the island, Greek terrorist organization EOKA did opt for the same course as was pursued by Hindu leadership of British India before Partition, which launched a Quit India Movement as soon as the Second World War began. In fact, the goals of EOKA and Hindu leadership were the same: to dominate Muslims. EOKA targeted the British in the 1950s so that they should quit Cyprus without reaching a long-term political settlement accommodating the Turkish Cypriot political and security concerns. The main motive behind EOKA terrorism against the British and Turkish Cypriots was to achieve Enosis.

The question that arises is, why didn't the British realize before withdrawing from Cyprus and establishing a federation there that chauvinistic Greeks, with terrorist EOKA in their midst, would never allow the Turkish Cypriots to exercise their right of political equality and live in a secure environment in a federal republic? Before the 1960 republic was established, the matter of Partition did surface during the House of Commons debates. ${ }^{11}$ The final settlement, however, was a federal republic. Thus, despite the fact that a Cypriot 'nation' did not in fact exist in Cyprus, the Turkish and Greek communities had reached an agreement to establish a Cyprus State in partnership. It had been hoped that out of this Cypriot State a Cyprus 'nation' would eventually emerge. This, of course, required time, goodwill, and cooperation between the two nations. ${ }^{12}$ Unfortunately, on all of these counts-time, goodwill, and cooperation-the Greek Cypriots failed the international community. Through acts of political discrimination and ethnic terrorism, they destroyed the Partnership Republic within three years of its establishment. Instead of showing goodwill to their Turkish Cypriot partners in the government led by Vice-President of the Republic, Dr Fazil Kuchuk, they evicted them from all the organs of the government and, until the July 1974 peace operation by Turkey, tried to ethnically-cleanse the Turkish Cypriot population. As far as the Greek Cypriot spirit of cooperation with the Turkish Cypriots is concerned, it is clear from their arrogance and obduracy in the decades-long UN negotiating process on Cyprus. Had the British also opted for 'divide-and-quit' solution in the case of Cyprus, for which they already had before them a precedent from the subcontinent, the issue of Cyprus would not have arisen in the first place. The two states of Cyprus would have progressed equally and effectively with security guarantees provided by their respective motherlands, Greece and Turkey. Although many factors are responsible for the messy situation facing Cyprus today, especially the Turkish Cypriots, the British must be partly blamed 
for creating this situation - and, therefore, they, more than any other Western power, are obliged to help correct it in an equitable manner. However, it remains a fact that the British have been more interested in the survival of their two sovereign military bases in Cyprus than any political settlement of the issue. Given the strategic location of the island, the British would obviously oppose any political settlement in Cyprus that threatened the existence of their sovereign military bases.

The 1960 Republic experience was a disaster, and, under no circumstances, it should be repeated. It is tragic that the United Nations and other principal players of the international system are still mostly trying to revive the fatally flawed model. The existing UN framework for resolution could have been valid for the period between 1963 and 1974. The territorial separation which followed the events of 1974 and well over three-and-a-half decades-long evolution of two fully-fledged sovereign and democratic states necessitates a new approach on the part of the international community to facilitate a new working relationship between the two island states. The separate existence of the TRNC is an established fact, and the level of Turkish Cypriot trust and confidence in the Greek Cypriots is so low that the formation of some kind of new partnership is highly unlikely. The physical separation of the two sides following the events of 1974 has prevented inter-communal violence and fighting, and provides a ground on which the foundations of new political arrangements on the island can be firmly built.

Given a long history of conflict and mistrust between the two nations, the establishment of a Federation would be counter-productive. A true federation in a sociological as well as a legal sense can only come about as a result of free self-determination of two partners, who hold an equal status at least as far as this freedom and power of self-determination is concerned. A federation, as a form of contact, cannot be otherwise envisaged than as a consent of partners who are considered able and entitled to decide and speak freely for themselves. Two parties, one of which is oppressed and governed by the other, cannot validly conclude a federation. Therefore, the establishment of the Turkish Republic of Northern Cyprus has provided a decisive prerequisite for what is considered by both parties as the solution to the Cyprus problem. It should be welcomed and recognized by everyone interested in such a solution. ${ }^{13}$

In case the international community wishes Cyprus to represent itself in world organizations and inter-states affairs as one country, then the idea of Confederation can be a workable option. However, since a Confederation is only possible between two or more states, the international community before trying this option has to give official recognition to the TRNC. Unlike Federation, which is created by a Constitution, a Confederation is established by an 
international treaty and represents a loosely coordinated structure between two, or more states whose decisions are not directly enforceable. The primary precondition for the creation of a Confederation, however, is that the states concerned should become so friendly with each other that they are willing to share crucial areas like foreign, defense and communication affairs. Looking at the Greek tactics of the past half century, how can anyone realistically even expect the Greek Cypriot leadership to share their foreign, defense and communication affairs with the Turkish Cypriots in a Confederation? Of course, they would like to have a Federation in which they could establish a majority rule on the island as a first step towards Enosis. The option of Confederation could have been possible, had the Greek leadership welcomed President Denktas's August 1998 proposal to this effect, which it has not. The option of Confederation could have been possible, had the international community acknowledged the right to statehood of the Turkish Cypriot nation, which it has not. In these circumstances, partition of the island into two independent states remains the only viable option.

In his book, Contemporary Cyprus, Dr Gobbi writes: "The idea of a binational Cyprus has not proved viable; it showed lack of capacity to maintain a common life...The idea of unification presents itself as sociologically irrational. In the case of Yugoslavia's fragmentation, the differences were only cultural. In the case of Cyprus, we have these differences, plus external, divergent forces in action, more today than in the past. Furthermore, there is nothing to constitute a uniting factor. What we do have is the existence of real confrontations and chronic prejudices. There are no cultural similarities, where language, religion and race are different. There is no will to share a common destiny, an important factor in multi-racial American societies. They also lack the desire to live in close association, since past experience has shown that coexistence has not led to the slightest inclination for integration. They do not share even common enemies as an external uniting factor. On the contrary, the foreign ties are separating factors. 'Quieta non movre', which in translation means let sleeping dogs lie, because unification might arouse ancient conflicts. Before you think of unity you have to transform the inter-communal psychological atmosphere. We are in the presence of two culturally different communities, separated by powerful new as well as old causes and nothing favouring union....In our days, nothing indicates unification; everything points to separation. The endeavour of the United Nations is very generous, but a step in the wrong direction. It was not well-grounded in the past, and it is less wise today, under changed circumstances." 14

Which other opinion on Cyprus can be more credible than that of Dr Gobbi, who directly mediated on the issue on behalf of the world's top most body set up on the ashes of the Second World War for the exclusive purpose of 
guaranteeing international peace and security? In fact, Dr Gobbi's has not been the only diplomatic voice suggesting the island's division into two independent and sovereign states as a means towards achieving a long-lasting settlement of the Cyprus issue. In the summer of 1964 , a similar solution was offered by US Secretary of State Dean Acheson, who proposed an effective Enosis together with the creation of Turkish military bases and Turkish Cypriot cantons in northern Cyprus and compensation for Turkey in Western Thrace and Catellonia. But both Makarios and Greece rejected the plan. ${ }^{15}$ The Turkish Cypriots were willing to accept it.

What becomes clear from the above discussion is that the main reason why Greek Cypriot ruling elites have not been forthcoming on any amicable settlement of the Cyprus issue since the 1963 break-up of the Republic of Cyprus is that all these years the status quo has favoured them. Recognized internationally since 1964, their so-called Republic of Cyprus has been solely benefiting from all the international trade and aid, including the share of Turkish Cypriots. Why should they compromise such a privileged position? The strategy they have adopted to continue the status quo is to delay political settlement on one pretext or another. When Turkish Cypriots were ready to accept the cantons settlement as proposed by the Acheson Plan, they were against it. For decades, the Turkish Cypriots were ready to negotiate the federation option. But the Greek Cypriots remained reluctant. Since August 1998, the Turkish Cypriots have been calling for the establishment of a Confederation, and, interestingly, the Greek Cypriot leadership has started to show interest in a federal settlement. Given that, if the Turkish Cypriot side really aims at securing a Confederation, then it should have better pronounced Partition. And, to its surprise, it might have found the Greek Cypriot elites inclined towards the Confederation idea.

All said and done, however, both historical realities and current circumstances seem to favour the partition option in Cyprus. Recognition or no recognition, the Turkish Cypriots are any way benefiting from enormous opportunities that the fast emerging international trend towards globalization provides them. The demands and pressures of globalization are fast solving the only unresolved issue in Cyprus: that of non-recognition of the TRNC. The international community is, thus, left with no option but to acknowledge the separate statehood, political independence and sovereignty of the Turkish Cypriot nation. Once this is done, then the two people living in their respective states in a divided Cyprus can always amicably deal with other areas of conflict while keeping their respective national interests supreme. Issues such as sovereign British bases (whose mandate can be re-negotiated after the 1960 international agreements lose their validity following the island's division), as well as other unresolved matters such as territorial readjustment, property exchanges, etc. 
In the given circumstances, the EU has two options: First, it can wait for political settlement of the issue, and if it is settled on the basis of a two-states confederation formula, then consider the membership application filed by a single Confederal authority of the two States. The second option for the EU, which I personally support, is to accept the division of the island into two States, after recognizing the TRNC, and then accepting a separate membership application of the Turkish Cypriot State. If the EU can separately accept the candidacy of the Czech Republic and the Republic of Slovakia - which not that long ago were a single State - why can't it separately accept the membership application of the two States of Cyprus? The same is the case with the three Baltic Republics of Latvia, Lithuania and Estonia - which were part of the Soviet State - all of them have been separately considered for EU candidacy. The European powers have to realize that membership of the TRNC and Turkey in the EU might, in fact, be a blessing for the European Union itself, since this will have a moderating impact on any future conflict of interest between Washington and Brussels in the Eastern Mediterranean.

By opting for the accession course for Cyprus, the EU has taken upon itself the additional responsibility of correcting the state of affairs in Cyprus. How can it do that? The most feasible way may be to accept the ground reality of a divided Cyprus - in the creation of which Brussels itself has played a vital role-and, on the basis of this reality, consider separately the Turkish Cypriot case for EU membership. Of course, bringing the two states of Cyprus into the European fold will be an uphill task - involving, in particular, significant European financial obligations to help the Turkish Cypriots bridge their gigantic economic gap vis-a-vis Greek Cypriots - but, at least, such a decision on the EU's part will enjoy the consent of the two people of Cyprus. Until this happens, Cyprus will remain a key factor in the Turkey-Greece-EU triangle. As regards the present time, while the Turkish leadership does not see any connection between its EU membership bid and the Cyprus issue, Greece links it with the settlement of Cyprus. However, the European Commission's approach on the matter seems to favour the Turkish stance. ${ }^{16}$

It is a good omen that relations between Turkey and Greece have improved since the August 17,1999 Marmara earthquake disaster in Turkey. It was only after that tragic event that Greece - which had been the leading opponent of Turkey's EU membership quest - reluctantly decided to say 'yes' to Ankara's EU accession bid-which, if seen in the historical perspective and the prerequisites that Turkey has to meet in accordance with the Copenhagen political criteria for EU membership as well as the economic and social standards that the EU has laid down for its membership, may turn out to be a long haul. The EU membership of Cyprus is not possible without Turkey's EU membership. It is also not possible without the availability of the Turkish Cypriot consent 
for the purpose. In the final analysis, the issue of Cyprus is linked directly to EU's enlargement and to Turkey's EU membership. And the recognition of the TRNC as an independent state, as the Turkish Cypriots demand, will be central to any political settlement of the Cyprus issue.

As 1999 ended, however, a glimmer of hope did surface on the Turkish Cypriot horizon - as the United Nations in two different cases within two months - November and December - appeared to acknowledge the fact that in Cyprus there existed "two sides", not just one state and one community. The first instance was when UN Secretary-General sent invitations to the two leaders of Cyprus for the resumption of UN proximity talks on December 3. Within hours after President Denktas objected to the wording of the invitation, the UN Secretariat had to change the text of the invitation while accommodating the Turkish Cypriot demand. ${ }^{17}$ That the "two sides" of Cyprus finally resumed UN proximity talks in December 1999, was a breakthrough. However, when the talks began, on December 3, UN SecretaryGeneral Kofi Annan warned that he did not expect a "miraculous solution" to the Cyprus problem. "We shouldn't have unrealistic expectations that at this round we are going to be able to solve the Cyprus crisis, but we are going to try to move the process forward," Mr Annan said, while hoping that the two leaders would concentrate on the "core issues."18 But the day when the talks concluded, Mr Annan said in an upbeat mood, "The new dynamic between Turkey and the European Union, and between Greece and Turkey, provides a hopeful context in which to continue these taks." 19 This indicates as to how positively the Helsinki summit impacted the UN negotiating process on Cyprus.

The second instance of the UN acceptance of the ground reality in Cyprus was the December 15 resolution of the UN Security Council pertaining to the six-month renewal of the mandate of United Nations Peace-Keeping Force in Cyprus (UNFICYP). The resolution stated, "Under the present circumstances, the presence of $\mathrm{UN}$ forces on the island remains indispensable for the maintenance of a ceasefire between the two sides." An addendum to UN Secretary-General Kofi Annan's November 29 report to the UN Security Council said: "UNFICYP can operate on both sides of the island only on the basis of the consent of both parties and that the Turkish Cypriot authorities (italics added) will accordingly request UNFICYP to work with them to develop modalities of UNFICYP's operation in northern Cyprus." Thus, for the first time since its March 1964 deployment on Cyprus, the UNFICYP was going to start its operation in North Cyprus under an agreement between the Turkish Republic of Northern Cyprus and the United Nations-a development tantamount to UN acknowledgement of the Turkish Cypriot state..$^{20}$ 
While the United Nations appears to be reshaping its Cyprus outlook in consonance with the ground realities on the island, the European Union has yet to officially synchronize its position with these realities. At least, by now, as a corollary to the recent developments, especially in the post-Helsinki period, it should have undertaken the most urgent step of lifting the 1994 European Court of Justice embargo against the TRNC. However, it is a fact that latest individual opinions from European think-tanks, such as the Centre for European Policy Studies (CEPS), have started raising some voice in favour of the Turkish Cypriots. In this context, one important work, which I have quoted throughout this paper, is Nathalie Tocci's study titled The 'Cyprus Question': Reshaping Community Identities and Elite Interests Within a Wider European Framework, which proposes that the EU should "incorporate the Turkish Cypriots in any relations but especially in negotiations between Cyprus and the Union...Turkish Cypriot elites have already proposed a political settlement within the EU provided the EU recognizes the Turkish Cypriot administration... Once the Turkish Cypriot community is fully incorporated in relations with the EU and both nations are ultimately included as full members of the Union, constructive role of the latter could be envisaged." ( $p 30$ ) Although Nathalie proposes the establishment of a confederal arrangement as "the first step towards the elimination of inter-communal barriers and the creation of a joint Cypriot nation-state"; on the basis of my argumentation above, I propose the creation of two independent states on the island as the first step towards the establishment of a two-states confederation, which, in time, can evolve into a federation-a long process in which the growing integration of the two nations of Cyprus in the EU will play the most important role. If one-time confederations can evolve into federations or unitary states, as Nathalie argues by citing the cases of the United States, Switzerland, Germany and the Netherlands, the two states of Cyprus can also agree to have a confederation at some stage in future. The very fact of their existence within the same island, of their increasing interaction and shared purpose as European partners, might help realize such an eventuality. It is true that the EU integration process impinges upon sovereignty of the EU member-states, but it also a reality that decades on the French have remained French and the British have remained British. Therefore, let the Turkish Cypriots enter the EU as Turkish Cypriots and Greek Cypriots, as Greek Cypriots. If Europe has to enlarge, Brussels has to duly recognize the freewill of nationalities in the acceding regions. Cyprus is no exception. 


\section{Endnotes}

${ }^{1}$ Turkish Daily News, 18 December 1999.

${ }^{2}$ For the summit conclusions, see http://, 12 December 1999.

${ }^{3}$ Cyprus Mail (12 December 1999) stated, "This wording did not make Cyprus's acceptance automatic, as member countries could still veto such a move....Greece's attempt at cutting the link between entry and a settlement to the Cyprus problem was not entirely successful."

${ }^{4}$ See Nathalie Tocci, The 'Cyprus Question': Reshaping Community Identities and Elite Interests Within a Wider European Framework (Brussels: Centre for European Policy Studies, 2000), p 21. Hereafter quoted as Tocci, The 'Cyprus Question'. Also see Los Angeles Times, 13 December 1999.

5 Turkish Daily News, 18 December 1999. Since then, President Denktas has toed the same cooperative line vis-à-vis the EU. For instance, in an interview to Turkish Daily News (22 January 2000), he said the EU's decision to accord Turkey candidate status had created a new situation. "Until Helsinki, when Turkey spoke about the Greek Cypriot bid to join the EU, the EU responded in chorus, "This is a matter for the EU. It's none of your business... No one from outside the EU can discuss this issue.' Or, the EU told Ankara that it has no right to intervene in Greek Cypriot-EU affairs. Now, Europe can no longer say such things because Turkey is not outside the EU... Turkey is now a candidate country. Therefore, Turkey can easily defend its position and its rights in Cyprus. Of course, Turkey will make every possible move to defend its rights, will continue its contacts and explain better the Cyprus problem to Europe."

${ }^{6}$ Nathalie Tocci, in 'The 'Cyprus Question' (p 5), admits that the Greek Cypriot elites see the "relation between the two ethnic communities as one of majority to minority, in which both enjoy equal individual rights but in which the former community would enjoy the supremacy in government." As for the Cypriot identity, Nathalie believes ( $p$ 13), "The absence of a joint Cypriot identity and the deep affiliations of the two communities to their respective motherland countries lie at the root of the 'Cyprus question'... It is crucial to note that in almost three centuries of coexistence, linkages between Greek and Turkish ethnic communities remained minimal." "New conditions have fuelled the emergence of distinct and contrasting identities and nationalisms between the two ethnic communities, which by giving rise to deep-rooted fears and misperceptions have prevented the integration of the peoples of Cyprus. After almost four decades of divisions, disparities and lack of contact, the emergence of a shared Cypriot identity and purpose, crucial to a long-lasting settlement of the conflict, has become an increasingly distant prospect." (p 14).

${ }^{7}$ For details, see Radha Kumar, "The Troubled History of Partition", Foreign Affairs, January/February 1997. 
${ }^{8}$ Such Partitionist views have been quoted by Elizabeth $\mathrm{H}$ Prodromou in her article, "Reintegrating Cyprus: The Need for a New Approach," Survival, vol 40, no 3 (Autumn 1998), pp 9-10. However, the article itself argues for a unified Cyprus. However, Nathalie Tocci in The 'Cyprus Question' ( $\mathrm{p}$ 19) defends the Turkish Cypriot right to political equality, as "The Turkish Cypriot state is fully equipped with a government, a central government, a judiciary and an administration, it is effectively secured by large police and military forces and it is recognized as the legitimate government in $37 \%$ of the island's territory."

${ }^{9}$ Elizabeth, contrary to the Partitionists' point of view, however, argues (pp 10-11) that "Partition would institutionalize the premise that the Greek and Turkish Cypriot communities are incapable of peaceful coexistence within a united state, thus diminishing the likelihood of long-term peace in regions with intra- and inter-state conflict along ethnic lines." She also writes that "by recasting relations between the two states in terms of hostile ethnic entities, partition would undermine the possibilities for Cyprus to become the key to broader Greek-Turkish rapprochement." Both of her arguments are fundamentally flawed. After the tragic events in Cyprus during 1963-1974, the very idea of "peaceful coexistence within a united state" looks ridiculous. And, as far as "broader Greek-Turkish rapprochement" is concerned, it depends upon many factors, of which Cyprus is only one. This rapprochement is already under way, ironically as a result of the August 1999 earthquake in Turkey-and any future regression or progression in this long-awaited process should be seen in the context of broader regional or international co-relation and competition of forces, rather than linking it with the situation in Cyprus, as Elizabeth does. Also see Ergun Olgun, "Cyprus: A New and Realistic Approach," Perceptions vol IV, no 3 (September-November 1999), 91-117.

${ }^{10}$ See Craig Baxter, et al, Government and Politics in South Asia (Boulder, Co: Westview Press, 1993), p 35. For details on the circumstances leading to Pakistan's creation, see Percival Spear, ed, The Oxford History of India, 3rd ed (London: Oxford University Press, 1967); and Stanley Wolpert, A New History of India (New York: Oxford University Press, 1982).

11 On 19 December 1956, the British Colonial Secretary in Cyprus, Allen L Boyd had stated that while giving independence to Cyprus the right to self-determination of the two nations would be considered equally; and that if the circumstances required the island could be "partitioned between the two nations" as a final settlement by Her Majesty's Government. The then British Prime Minister Harold Macmillan had later seconded Secretary Boyd's opinion in the House of Commons. For details, see Ishtiaq Ahmad, After Bosnia: Cyprus? (Vision 21 Publishers, 1997), 33-34.

${ }^{12}$ See Necati Munir Ertekun, The Cyprus Dispute and the Birth of the Turkish Republic of Northern Cyprus (London: Oxford University Press, 1981), p 8. On the question whether the 1960 Republic was meant to be a State or a Nation, Mr Ertekun cites a statement by Archbishop Makarios (Cyprus Mail, 28 March 1963): "No Greek, who knows me can ever believe that I would wish to work for the creation of a Cypriot national awareness. The Agreements (of 1960) have created a State not a Nation." 
${ }^{13}$ Dr Christian Heinze, Cyprus Conflict, 1964-1985 (London: K Rustem and Brother, 1986), 343. Dr Heinze has been quoted by Metin Tamkoc in his excellent work, The Turkish Cypriot State. Metin comments: "The Turkish Cypriot people were entitled to their own State. They have established their State, in the exercise of their inherent and inalienable right of self-determination. The legal existence of this State is not, however, contingent upon its recognition by other States. Its legal existence is the function of its legitimacy. The formal aspects of the Turkish Republic of Northern Cyprus - its type of government, the size of its population and its territory, its physical capabilities - are not as important as its 'Spirit.' As long as that 'Spirit' represents 'the free will of the Turkish Cypriots' it deserves respect among other States. The legitimacy of the Turkish Republic of Northern Cyprus is the only reason why it must be accorded recognition., not only by the Greek nation but also, by the whole society of nations. The latter must regard such an act of recognition of the Turkish Republic of Northern Cyprus as fulfillment of one of their significant international duties." For details, see Metin Tamkoc, The Turkish Cypriot State: The Embodiment of the Right of Self- Determination (London: K Rustem \& Brother, 1988), 81-139.

14 For more details, see Hugo J. Gobbi, Contemporary Cyprus (Tel Aviv: Auropa, 1998), 181 p. Also see Hugo J. Gobbi, Rethinking Cyprus (Tel Aviv: Auropa, 1994), $110 \mathrm{p}$.

15 Tocci, The 'Cyprus Question', 7. Also see Omer Murat, "Taksim was Offered by the US," Turkiye, 20 September 1999.

${ }^{16}$ Gunter Verheugen, EU's Commissioner for Enlargement, in an interview published in the Turkish Daily News of 26 November 1999, stated, "Turkey's EU candidacy has nothing to do with the Cyprus issue."

${ }^{17}$ President Denktas objected to the wording of the UN invitation, which mentioned him as "Turkish Cypriot leader Mr. Denktas", and to Mr Clerides as the "President" of the "Republic of Cyprus". The mistake was corrected, by terming the two leaders as "His Excellencies." Yusuf Kanli, "Cyprus Inches Towards New Round of Talks, But Pessimism Persists," Turkish Probe, 21 November 1999.

18 Turkish Daily News, 3-4 December 1999.

${ }^{19}$ Cyprus Mail, 15 December 1999.

${ }^{20}$ Nathalie Tocci, in The 'Cyprus Question" (p 21), writes, "Although the latest UN Security Council resolution of 15 December extending the term of the UNFICYP did not include references to the Turkish Cypriot state, Kofi Annan's addendum following the first round of proximity talks of December 1999 included a clear acknowledgement of the Turkish Cypriot state. This marginal change in UN position may well affect bargaining positions of the two elites and render Denktas's call for international recognition a more realistic bargaining stance." Also see Cyprus Mail, 17 December 1999. 